\title{
Dydaktyka przeciwko dydaktyce
}

\section{KEYWORDS}

didactics, study, politicization, exodus

\begin{abstract}
Szwabowski Oskar, Dydaktyka przeciwko dydaktyce [Didactics against didactics]. Kultura - Społeczeństwo - Edukacja nr 2(14) 2018, Poznań 2018, pp. 73-86, Adam Mickiewicz University Press. ISSN 2300-0422. DOI 10.14746/ kse.2018.14.6.
\end{abstract}

The paper elaborates on the concept of the didactics of immanence. Relying on the discussion contained in a text entitled "Polityczność dydaktyki" ("Politicisation of Didactics"), it differentiates between two types of didactics, one related to transcendence and the other to immanence. Using the theoretical accomplishments of Deleuze and Lewis, the author creates a plan to build an educational machine of war.

\section{Wprowadzenie}

W artykule dokonam dalszego rozrysowania różnicy między dydaktyką immanencji a dydaktyką transcendencji. Pierwszy ruch został wykonany w tekście Polityczność dydaktyki (Szwabowski, 2017) w kontekście polityczności teorii i praktyki dydaktycznej. Wykazałem tam istotową różnicę między politycznymi uwikłaniami partyjnymi, postpolitycznymi, mikropolitycznymi oraz krytycznymi a politycznie postpolitycznymi. Odwołując się do podziału zastosowanego przez Joannę Bednarek na politykę transcendencji i politykę immanencji (Bednarek, 2012), dowodziłem, że to ostatnie dotyczy jedynie politycznie postpolitycznego modelu. Wydaje się, że tak jak między politycznością transcendencji a politycznością immanencji istnieje radykalna przepaść - nie tyle traktowałbym je jako bieguny, jak czyni to Bednarek, ale raczej jako sposoby istnienia - tak samo w przypadku różnicy między dydaktyką transcendencji a dydaktyką immanencji mamy do czynienia $\mathrm{z}$ dwoma odmiennymi sposobami istnienia i myślenia tego, co dydaktyczne. 
Wspomniane rozważania dotyczące form polityczności miały jedynie charakter wprowadzający, porządkujący myślenie o polityczności dydaktyki, z tego powodu były one nacechowane dość wysokim stopniem abstrakcyjności. W niniejszym artykule kontynuuję swoje rozważania w kontekście samej dydaktyki, zastanawiając się nad konsekwencjami dla tej dyscypliny, gdy zastosuje się wspomniane pojęcia. W pierwszej części wskażę, że różnic między dwiema dydaktykami nie można ujmować w kategorii paradygmatu, ale różnica ustanawia się między tym, co paradygmatyczne, a tym, co nieparadygmatyczne. Następnie, podążając tym tropem, postawię pytanie o pragnienie naukowości wpisane w oba sposoby myślenia i działania dydaktycznego i miejsce teorii. To zaś poprowadzi do pytania o sam status dydaktyki ogólnej. Z perspektywy dydaktyki immanencji teoria nie jest czymś, co zostaje nadbudowane nad praktyką, ani też czymś, co poprzedza praktykę, jako rodzaj instrukcji obsługi. Dodatkowo, nie istnieje nic, co jest ogólne, żadne uniwersalne przepisy na dobre zajęcia i wyśmienite kształcenie. Dodatkowo, o ile dydaktyka immanencji jest pojedynczym wydarzeniem, niemożliwym do reprezentacji, ujęcia w słowach, to muzeum, którym mogłaby być dydaktyka ogólna, jest muzeum ruin, wyblakłych zapisów, nieporozumień i złych przekładów. Dydaktyka immanencji jako radykalnie odmienna wizja i sposób istnienia, pozbawiona pragnienia stania się naukę, wytwarza też własne formy zapisu, nowy język i problemy. Zamiast tworzenia raportów, opisów i przepisów, kieruje się w stronę intensyfikowania, performowania i prowokowania. Z języka pozytywistycznego przechodzi w języka poezji, metafor i plemiennego slangu. To przesunięcie w stronę nie-raportów (D’Hoest, Lewis, 2015) odciska też piętno na niniejszym artykule, który nieumiejętnie oscyluje między pragnieniami.

\section{Paradygmat i to, co nieudomowione}

Stwierdzenie o wieloparadygmatyczności nauki jest już banałem. Znamy mantrę dotyczącą niewspółmierności paradygmatów, jak również próby dyscyplinarnego radzenia sobie z wielością poprzez postulowanie świadomego i konsekwentnego lokowania się w którymś z nich. Mimo że myślenie to zadomowiło się w pedagogice i dydaktyce, to jest ono problemowe. Myślenie paradygmatami w dydaktyce nie tyle wprowadza ład, co narzuca pewną specyficzną logikę zarówno praktyce, jak i teorii dydaktycznej. Jest to myślenie techniczne, sam paradygmat jest zbiorem sposobów rozwiązywania konkretnych problemów w oswojonym i rozpoznanym świecie, w ramach ustalonych już gier. Jest on sposobem dyscyplinowania i zamykania świata, rugującym filozoficzność jako wstydliwą przeszłość, źródło 
niepewności i nieproduktywną refleksję (Kuhn, 2001). W tym sensie paradygmaty stają się maszynami dydaktycznymi': zbiorem spójnych, doskonale pracujących trybików, produkujących niemalże automatycznie określone efekty (Szwabowski, 2014a). Pozwala to niby określać prawidłowości i projektować proces kształcenia przed wszelkim realnym spotkaniem. Niestety, to projektowanie, rady i plany nie są czymś neutralnym. Wytwarzają one i dyscyplinują organy, blokując przepływy wewnętrznych pragnień, łamiąc kłącza (Deleuze, Guattari, 2015), dokonując reakcyjnych i represyjnych zapisów (Deleuze, Guattari, 2017). Mówiąc inaczej, bogactwu, niepowtarzalności, pojedynczości wydarzenia narzucają techniczne reguły, chaosowi biurokatyczny porządek, poezji słów laboratoryjną jednoznaczność.

Myślenie paradygmatyczne może wydawać się pozbawione pozytywistycznych naleciałości, a nawet postmodernistyczne. Niestety, postmodernizm może należeć jedynie do sfery deklaracji, zwłaszcza gdy zawęzi się analizę do dokonań dydaktyki. Pozytywistyczne myślenie przesiąka koncepcje paradygmatów, doprowadzając do panowania racjonalności instrumentalnej, do technicznego ujmowania kształcenia - dotyczy to również paradygmatu krytycznego, który odpowiada wyodrębnionemu przeze mnie uwikłaniu krytycznemu (Szwabowski, 2017). W kontekście kierunku i rozwoju dydaktyki jej część paradygmatyczna staje przed następującą alternatywą: albo akceptacja racjonalności instrumentalnej i technokratyczne zarządzanie kształceniem skoncentrowanym na usprawnianiu wydajności określonych maszyn i akademickim czuwaniem nad brakiem sprzeczności, swoistą czystością rasową paradygmatu, albo, poprzez wykazanie technicznego charakteru każdego paradygmatu, uwikłanie dydaktyki w jawny lub skryty pozytywizm oraz ducha biurokratycznego, doprowadzić do zniesienia myślenia paradygmatycznego i związanej z tym stylem myślenia dydaktycznego.

Przy tak rozumianym paradygmacie mógłbym przypisać paradygmatyczność dydaktyce transcendencji, zaś dydaktyce immanencji antyparadygmatyczność. To jest istotna różnica. Dydaktyka immanencji nie jest zdefiniowaną grą, nie jest rozpoznanym światem, w którym wyłaniają się jedynie techniczne problemy, nie ma też sposobów rozpoznawania chaosu.

Ujmując problem politycznie, dydaktyka paradygmatyczna stanowi maszynę wspierającą biopolityczne zarządzanie właściwe polityce transcendencji. Nie tylko wiąże się z kapitalistycznym imperatywem rozwoju i fiksacją na efektach (Lewis,

${ }^{1}$ Maszyna dydaktyczna jest maszyną zamykającą świat, prezentującą go jako dany, zastygły i rozpoznawalny w pewnych i jasnych formach. Jest też maszyną hierarchizacji i reprezentacji, maszyną odtwarzania i reprodukowania. W przeciwieństwie do niej, maszyna wojenna jest horyzontalną siecią przepływów, otwierającą świat, traktującą go jako coś zadanego, przestrzeń kreacji, tworzenia i wyłaniania się nieznanego (zob. Laskowski, 2011; Szwabowski, 2014b). 
2013), ale również nie jest w stanie uchwycić autonomii tego, co oddolne, wpisując się w praktyki korumpowania wielości (Negri, Hardt, 2012; zob. Szwabowski, 2014c) - starając się narzucić współliniowość pragnień i ogólnych celów panującego systemu (Lordon, 2012). Dotyczy to zarówno praktycznego, jak i teoretycznego wymiaru dydaktyki - o ile wymiary takie można wyróżnić. Tymczasem dydaktyka antyparadygmatyczna jest stawaniem się, horyzontalnym ruchem, czymś nieustannie nowym, nierozpoznanym, niespodziewanym - czymś, co zaskakuje i jest nienazwane.

\section{Naukowość a współbycie}

Dydaktykę w jej transcendencji, biurokratycznym i technicznym pragnieniu, utrzymuje nie tylko nieszczęsne odkrycie paradygmatów, ale również próba dowodzenia, że jest nauką. Tak jak opowiadam się za odrzuceniem myślenia paradygmatycznego, tak samo wskazuję na potrzebę rezygnacji z naukowości. Naukowość może być czymś, i często jest, co wywłaszcza nas nie tylko z wiedzy, ale z egzystencji, jak w przypadku filozofii, która przeradza się w dziedzinę uprawianą przez państwowych urzędników. Nauka nie jest jedynym, ani nawet uprzywilejowanym, sposobem relacji ze światem i z innymi. Stanowi niekiedy toporny styl myślenia, który uniemożliwia dotarcie do tych wydarzeń, tych przejawów życia jednostki i wspólnot, które dla dydaktyki są istotne. Naukowość nie tylko jest blokadą, pewnym treningiem "niewidzenia” i specyficznego widzenia (o nauce widzenia i niewidzenia zob. Lewis, 2012a), co niekiedy staje się niebezpieczna, zwłaszcza wtedy, gdy zostaje ona utożsamiona z wiedzą ekspercką. Mamy w takiej perspektywie postpolityczną, czy też szerzej: transcedentalną polityczność, która próbuje zapanować nad immanentnością „chaosu”. Model transcendencji ujawnić może wtedy swoją moc suwerenną w pełnej, mrocznej okazałości, podporządkowując życie matrycy wytworzonej przez administratorów (Bauman, 2009). Naukowość, w której duch scjentyzmu jest wiecznie żywy, poszukując tego, co ogólne, powtarzalne, pragnąc praw i jasności, pewności, odwraca się od przypadkowości i chaosu życia, od stawania się i tego, co niepowtarzalne. W odgórnym, wzniosłym spojrzeniu działa niczym „maszyna dydaktyczna" (Laskowski, 2011), zszywając i reifikując świat. Sprowadzając go do zbioru danych-rzeczy, którymi kierują ogólne siły, w zaklętym kręgu powtarzalności i tego, samego. Jej pragnienie, jest pragnieniem władzy: zapanowania nad światem, nad ludźmi, nad procesem dydaktycznym - zamiast zanurzenia się w procesie, podążania nim i intensyfikowania stawania się. 
Dydaktyka immanencji nie ma zewnętrzności, nie jest spojrzeniem wywyższonym, zewnętrznym i pragnącym podporządkowywać oraz kierować. Rezygnuje z naukowości na rzecz realnych spotkań, czyli musi się stać ona istotowo filozoficzna, gdzie filozofia wraca do źródeł, do połączenia z egzystencją mędrca-koczownika, czy może raczej plemion - „Wszelka myśl jest już plemieniem, przeciwieństwem państwa” (Deleuze, Guattari, 2015: 464). Zamiast poszukiwać prawidłowości, którymi zarządzać mogą technokraci, zanurza się w konkretnym, niepowtarzalnym wydarzeniu (które jest czymś pojedynczym, zob. Massumi, 2011, rodzajem mesjańskiego cięcia, zob. Bey, 2001): „nauki podróżne czy koczownicze nie predestynują nauki do objęcia władzy ani nawet do samodzielnego rozwoju. Nie mają po temu środków, ponieważ podporządkowują wszystkie swe procedury zmysłowym warunkom oglądu i konstruowania, podążając za strumieniem materii, śledząc i łącząc gładką przestrzeń” (Deleuze, Guattari, 2015: 459).

Horyzontalny charakter dydaktyki immanencji wyklucza wszelką zewnętrzność, właściwą korupcyjnemu charakterowi nauki królewskiej. W ramach immanentnie rozumianej dydaktyki proces kształcenia jest tworzony podczas spotkania, nieustannie modyfikowany, nie tyle przez nauczyciela-menadżera, co przez samo złożenie. Zdecentrowanie nauczyciela, rzeczywista równość, wymaga nieustannego negocjowania wszystkich ze wszystkimi, wspólprodukowania w ramach pirackich sieci edukacyjnych (Lewis, 2012b), które obejmują znacznie więcej niż ludzkie intelekty, znacznie więcej niż ludzkie ciała (zob. Gale, Wyatt, 2018; Lewis, 2010). Spotkanie jest czymś nieskończonym, a zarazem czymś chwilowym. Czymś, czego nie można powtórzyć. Czymś, co nie może być oceniane przez efekty. Czymś, co nie redukuje się do danych, do zbioru elementów. Czymś, co nie ma reprezentacji, a każdy obraz jest kłamstwem² ${ }^{2}$

Przykład dydaktyki immanencji, jak i nieporozumień wokół niej, może stanowić ruch Occupy Wall Street. Dostrzegamy w tym przypadku zarówno manifestacje stawania się, jak i próby wyjaśniania, które kierowane są inną logiką, nakładają kliszy itd. Ruch OWS był stawiającą się wielością i praktyką oporową, która nie tyle wysuwała żądania i włączała się w istniejącą politykę, co wytwarzała nowy świat w skorupie starego (Roos, Oikonomakis, 2013). Krytyka nieefektywności OWS jest, z perspektywy proponowanej w niniejszym artykule, przykładem „niewidze-

\footnotetext{
${ }^{2}$ Nie oznacza to, że nie można podjąć prób - i to przekonujących - przekładu, reprezentacji, wyjaśnienia. Przykładowo to, co się dzieje podczas spotkania, można tłumaczyć za pomocą paradygmatu konstruktywistycznego czy humanistycznego, jednocześnie proponując „pomoc” prowadzącemu, starając się „ulepszać” działania. Tylko że oznacza to nic innego, jak nałożenie starych struktur, wytartych klisz interpretacyjnych, na unikalność wydarzenia, a tym samym proces łamania kłaczy, likwidacji tego, co osobliwe (Deleuze, 2016).
} 
nia" i wyjaśniania polityczności za pomocą logiki transcendencji. Krytyka taka nie dostrzega nie tylko autonomii wielości, ale również specyfiki polityki wypracowanej podczas danego wydarzenia, odrębnych stylów uczenia się, studiowania czy szerzej, odrębności rzeczywistości OWS (Lewis, 2013; De Zeeuw, 2014; Hannon, 2014; Szwabowski, 2015). Autonomia, specyfika wydarzenia z punktu widzenia „tradycyjnie” ujętej polityki jest nie do zrozumienia, pozostaje jedynie zredukowana do tego, co znane i oceniona według zewnętrznych kryteriów. To, co istotne, OWS jako wydarzenie, sposób innej egzystencji, pozostaje niewidoczne. Niemożliwość przechwycenia maszyny wojennej OWS przez Państwo prowadzi do jego likwidacji, zarówno fizycznej, jak i na poziomie myśli (Deleuze, Guattari, 2015).

Innym momentem ujawniającym granice dydaktyki transcendencji z jej wizją naukowości i pragnieniem menadżerskim, technologicznej kontroli, był projekt „Autoetnografie studiowania”, w którym uczestniczę wraz ze studentami³ $\mathrm{W}$ trakcie jego realizacji spotykałem się z osobami prezentującymi humanistyczne podejście, tak samo jak z tymi, którzy chcieli motywować grupę za pomocą kar i nieustannego nadzoru, inni zaś proponowali poddawać wszystko pod dyskusje, w przeciwieństwie do tych, co próbowali nakłonić mnie do bycia nauczycielem. Moje lewicowe krytyczne podejście ścierało się z prorynkowym, z antydemokratycznym, liberalnym i różnymi, wielorakimi mutacjami, swoistymi kolażami ideologicznymi. W tej wielości podejścia przeplatały się, raz dominowała jedna strategia, raz inna - sprzeczności, chaos stanowiły nieusuwalny element współdziałań. Płynność, chaos jawiły mi się niekiedy jako wyraz mojego słabego obycia dydaktycznego, jako wynik braku umiejętności. Z drugiej strony, próby organizacji bez dyskusji, planowania, wypaczały ideę projektu jako autonomicznego wyjścia poza wyalienowaną edukację (Cleaver, 2012) i dydaktykę technologiczną (Malewski, 2010). Nie lokowaliśmy naszego działania w ramach jakiegoś paradygmatu, a jedynie otwieraliśmy się na możliwości. Myślę, że paradygmat nie był nam potrzebny. Mało tego, paradygmat pozbawiłby nas wędrówki, wspólnego błądzenia, uczenia się od siebie, odnajdywania się w mroku, wskrzeszania płomieni, gdy gasł w to w jednych to w innych dłoniach. Nieparadygmatyczność sprawiała, że się gubiliśmy i razem wędrowaliśmy. Była to „nauka błądząca”, zawsze nieczysta, zawsze rozmyta, brudna i konkretna (Deleuze, Guattari, 2015: 451). Paradygmatyczne podejście wygasiłoby wydarzenie nim by się pojawiło. Narzucałoby mapy i sposób stawiania kroków, tempo poruszania się i czas na biwakowanie. Wojskowy rytm, podporządkowujący maszynę wojenną aparatowi państwa. Tymczasem

\footnotetext{
${ }^{3}$ Projekt realizowany od roku 2015 w ramach prac Katedry Dydaktyki Ogólnej Uniwersytetu Szczecińskiego.
} 
my, koczownicza horda, podczas projektu, tak mi się to jawi, nieustannie rysowaliśmy, kreśliliśmy fantastyczne mapy - każdy inne, ciągle inne (Kaczmarek i in., w druku). W takim sensie, w jakim było to działanie antyparadygmatyczne, otwierające, w takim sensie było ono „nienaukowe”. Po zakończeniu, nie byłem w stanie powiedzieć, co się dokładnie wydarzyło (zob. Szwabowski, Wężniejewska, 2017). Współbycie pozostawiło ruiny, a nie dane (por. Lewis, 2017).

\section{Poezja wydarzenia}

Projekt „Autoetnografie studiowania” nie tylko sproblematyzował naukowość i role wiedzy dydaktycznej, ale też postawił nas przed zagadnieniem raportu, kwestią roli za-pisywania tego, co się wydarza i - tym samym - możliwości wypracowywania teorii w ramach dydaktyki immanencji. Kwestia ta ujawnia kolejną istotną różnicę między dydaktyką transcendencji a immanencji.

W technicznie zorientowanej dydaktyce, nastawionej na rozwiązywanie (abstrakcyjnie) konkretnych problemów ${ }^{4}$, spisanie raportu jest logiczną konsekwencją zewnętrznej, instrumentalnej racjonalności, z łatwością przeskakującą na poziom reprezentacji i urzeczowienia. Inaczej w przypadku dydaktyki immanencji raport wydaje się zdradą. Niewybaczalnym zakłamaniem i brutalnym zawłaszczeniem, które skazane jest na utratę swoje „przedmiotu”, dokładnie w tym momencie, w którym wydarzenie uzna za przedmiot. Raport staje się niemożliwy, a wszelkie odwołania do wspomnianego projektu bardzo ryzykowne - zwłaszcza gdy w euforii zaczynam używać „my”. „Ja” niestety nie rozwiązuje problemu, gdyż zatarciu ulega różnica między „ja-piszącym”, a „ja-będącym-wtedy-z-innymi”, „ja-stającym-się-nimi”, „ja-stającym-się-projektem”, kobietą, mężczyzną, studentami, nauczycielem, badaczem, tułaczem, dłońmi piszącymi... Zgodnie z logiką wydarzenia między upodmiotowieniem w wydarzeniu a poza wydarzeniem istnieje radykalna różnica, wprowadzająca maszyny tłumaczące na jałowy bieg.

Świadomość wspomnianych trudności skierowała mnie w stronę eksperymentowania $z$ raportami i tworzenia nie-raportów. Zaproponowałem uczestniczkom i uczestnikom napisanie wspólnej relacji z projektu. Dzięki temu miałem nadzieję uniknięcia reprezentowania i redukowania głosu uczestników do danych, zasobu, poddanych następnie naukowym operacjom przez ja-badacza. W moim odczuciu nie-raport stał się kolejnym, osobnym wydarzeniem, jedynie luźno związanym z tym, co miało miejsce wcześniej. Mało tego, wielość spotkań wokół pisania spra-

\footnotetext{
${ }^{4}$ Nauka królewska nie jest konkretna, bo nie potrafi płynąć ze strumieniem.
} 
wiała, że każde takie spotkanie miało własną dynamikę, własne upodmiotowienia i prawa, a samo pisanie nie tyle było reprezentacją, wyjaśnianiem, co techniką podtrzymująca złożenie, intensyfikująca współbycie, współ-stawanie się (szerzej zob. Pławski i in., 2018).

Ponadto, typowy słownik zaczynał się kruszyć. Staliśmy się obcymi we własnym języku. Ja w swojej dziedzinie. Cele? Efekty? Dajcie nam spokój, biurokraci. Dawno to, co założyłem, przestało mieć znaczenie, pojedynczości odnajdywały coś, niekiedy wspólnego, niekiedy innego, i ukazywał innym, co znalazły. Albo zostawiały to dla siebie, albo nic nie znajdowały. Studiowanie pochłonęło nas, stało się celem samym w sobie, miejscem, w którym zamieszkaliśmy. Lub nie. Ludzie opuszczali obóz, czasami coś wyjaśniając, niekiedy w milczeniu czy trzaskając drzwiami. Studiowanie pochłaniało, wyczerpywało, wywoływało konflikty zarówno z władzami, jak i wśród uczestników czy studentów, którzy nie mogli dopasować się do dziwnego stylu. Albo majaczyło, ciała włóczęgów przybierały monstrualne kształty. Może stawali się po prostu niewidoczni. Również dla mnie.

Poszedłem do Croatan? Poszli do Croatan? Poszliśmy do Croatan? Czy widzicie zielonookich Indian? (zob. Bey, 2001).

Kryzys słownika to też kryzys stylu. Tak jak typowo „naukowy” słownik dyscypliny stawał się toporny, tak też próby typowo akademickiego pisania stawały się niemożliwe. Intensyfikowanie współstawania się wymagało przejścia w stronę sztuki, języka poezji i ulicy, slangu i prowokacji. Język, tak jak i wiedza produkowana w ramach złożeń, stał się przedmiotem swobodnej gry - wytwarzał efekty, a nie reprezentował. Tworzył, a nie odkrywał. Zaskakiwał zamiast dawać prawa. był jednym z tworzyw, które sklejało nomadyczne maszyny wojenne.

\section{Dydakłyka ogólna jako muzeum ruin}

Wymienione trzy granice, trzy różnice, stanowią wyzwanie dla akademicko-potocznej dydaktyki w jej zanurzeniu w pragnieniu menedżerskim, pozytywizmie z jego technologicznym nastawieniem. Przede wszystkim, antyparadygmatyczność, antypozytywizm, niemożliwość raportu, który nie byłby zdradą, kłamstwem, reprodukowaniem dominujących wyjaśnień iluzji własnych i dyscypliny, stawia przed dydaktyką ogólną istotne wyzwanie, wyzwanie, które rzuca całej królewskiej nauce: jej autonomii. Przyjmując immanentną wizję dydaktyki, musimy odrzucić pozytywistyczne nastawienie, aby tworzyć prawidłowości mogące być implikowane, służące mniej lub bardziej szczegółowemu opracowywaniu procesu kształcenia 
oraz oceniania jego przebiegów i efektu końcowego. Ponadto, w ramach immanentnej dydaktyki nie ma miejsca na reprezentacje, a już tym bardziej uogólniania doświadczeń wydarzenia.

Niemożliwość napisania raportu i zmiana słownika, jak i odrzucenie paradygmatu oraz nauki, wiąże się z wyłonieniem innego zespołu problemów. Przykładowo, efektywność, wydajność, efekty, wyodrębnione metody nie stanowią już przedmiotu zainteresowania, zamiast tego współrozważa się, w konkretnych warunkach, melancholię studiowania, wyczerpanie, wygnanie, wycofanie - które nie są od razu jednoznacznie traktowane jako problemy, co raczej jako elementy mapy, które mogą być szlakami, istniejącymi o tyle, o ile nimi się podąża.

Tak ujęty zespół problemowy dydaktyki immanencji nie może zostać sprowadzony do kwestii techniki. Nie-raport nie jest również opisem. Skoro nie-raport nie odkrywa praw ani prawd, o ile pisanie nie-raportów jest integralnym elementem samego procesu, to kwestionuje to również pozytywistyczne rozdzielenie na teorię i praktykę. Teoria, w ramach dydaktyki immanencji, nie jest uogólnieniem i usystematyzowaniem doświadczeń, nie jest również ogólną refleksją nad procesem dydaktycznym, nie jest zbiorem twierdzeń, które się stosuje, martwą wiedzą, którą ożywia się w trybie zombie w klasie czy innej przestrzeni, formalnej i nie, edukacji. Teoria nie jest nad ani pod, jest w i to nie jako wyodrębniony byt. W kontekście powyższych ustaleń klasycznie (podręcznikowo) definiowane cele dydaktyki jako dyscypliny akademickiej przestają obowiązywać, są językiem nie tyle obcym, co nawet wrogim. W ramach dydaktyki immanencji rola dydaktyki ogólnej jako dyscypliny akademickiej ulega transformacji.

Można też, zaostrzając myśl, zastanowić się, czy nie ulega ona zniesieniu, gdyż jako „ogólna” zdaje się przynależeć do nauki królewskiej, z konieczności przeskakując na poziom autonomii i reprezentacji, zajmując się przedmiotami. Możliwe, że dydaktyka ogólna jako dyscyplina mogłaby stanowić muzeum, w którym tworzyć się będzie kolekcje ruin pozostałych po spotkaniach, gromadzić efemeryczne zapisy minionych sieci, urywki zdań nieznanych autorów, melodii i nastrojów; stosy nie-raportów, które stają się tajemnymi księgami, gdzie określona praktyka duchowa stanowi klucz interpretacyjny, otwierając na magię słów. Muzea dydaktyki ogólnej nie gromadzą już wiedzy pewnej, recept i przepisów, lecz rozmazane ślady, mogące nas zainspirować do wędrówki. Dydaktyka ogólna jako nie-nauka staje się wtedy skazanym na porażkę stróżem spotkania i poetą wychwalającym i budzącym pragnienie wędrówki w nieznane, skoku w otchłań. Niemniej, kolekcjonowanie nie może być rozumiane jako proces zawłaszczania klejnotów nomadycznych hord, ale jako nomadyczna odbudowa kłączy, co podważa wszelką ogólność, uniwersalizację, na rzecz wielości. 
„Zrywając z przymusem użyteczności i akumulacji, ucieleśniona wartość, podobnie jak miłosne tłumaczenie, nie mogła polegać na katalogizowaniu rzeczy, zdarzeń czy tekstów. Sednem kolekcjonerstwa byłoby odbudowywanie za pomocą kolekcji kłączy połamanych przez kapitalistyczną deteorytorializację" (Pospiszyl, 2016: 141). Nie chodzi tutaj o zapisywanie przeszłości, podporządkowanej policyjnym archiwom, ale o „danie głosu”, o uruchomienie określonych praktyk, o odbudowę tego, co została wyparte, wykarczowane przez naukę królewską i maszyny akumulujące. Kolekcja opisowi, wnioskom, sądom, przeciwstawia aforyzm (Deleuze, Guattari, 2015: 464), ich zestawienia, bojowe konstelacje.

Wspomnianego zatopienia się w praktyce nie należy traktować jako redukcjonistycznego stanowisk, przeciwstawiającego abstrakcyjnej teorii, konkretną praktykę. Myślenie w tych kategoriach wymagałoby uznania istnienia poziomu teoretycznego i praktycznego, a tym samym wiązałoby się z pewną zewnętrznością czy/i wertykalną wizją bytu, obu tych cech brak w immanencji. Nie należy rozumieć też tego jako dowartościowania każdej praktyki. Powtarzając: praktyka dydaktyki immanencji to praktyka związana $\mathrm{z}$ wydarzeniem albo, ujmując to innymi słowami, ze studiowaniem (Lewis, 2013).

\section{Praktykowanie jako nie-badanie}

Odrzucenie naukowości, podziału na teorię i praktykę, jak również zastąpienie tego, co ogólne, tym, co pojedyncze, niepowtarzalne i niereprezentowalne, stawia przed dydaktyką ogólną wyzwanie, które może wyrażać się jej zniesieniem. Proponowane zatopienie się w wydarzeniu i jego intensyfikowanie oraz gromadzenie tego, co zostało, jako inspirujących kolekcji, może zostać odczytane jako dowartościowanie praktyki i mistrzostwa poprzez działanie. Byłoby to jednak błędne odczytanie.

Stanowisko, które prezentuje, jest modyfikacją i radykalizacją myśli Zaczyńskiego (Zaczyński, 1988). Zgadzając się z tym, że pozytywistyczne, scjentystyczne nastawienie nie jest $\mathrm{w}$ stanie dostrzec specyfiki dydaktyki, jak również z proponowanym punktem wyjścia, wiążącym się z praktyką, nie uznaję możliwości tworzenia wiedzy opartej na licznych doświadczeniach. Praktyka, o której mówię, to praktyka wydarzenia.

Wydarzenie jest pojedyncze, to oznacza, że wszelkie próby powtórzenia skazane są na porażkę. Trudno też mówić o możliwości przekładania doświadczenia $\mathrm{z}$ jednego wydarzenia na drugie. W pierwszy przypadku, to, co było, oddziela nas od tego, co jest. Poprzez porównania nie możemy otworzyć się na to, co nadchodzi, staje się. Stosując kalkę, zapominamy, że to złożenie jest innym złożeniem, 
mającym własną dynamikę. Próba kopiowania blokuje jej rozwój. Może doprowadzić do „złej” melancholii i rozbudzić pragnienie technologiczne, aby zorganizować proces tak, by stawał się powtarzalny i to, co wyjątkowe, stało się powszechne. Następuje koncentracja na odtwarzaniu, a nie tworzeniu. To złe pragnienie niejednokrotnie sprawiało, że projekty się rozpadały.

Wydawać by się mogło, że kolejne projekty sprawią, że będę działać coraz lepiej, że mniej błędów będę popełniał. W takim myśleniu ujawnia się rys technologicznego myślenia o dydaktyce. Zakłada, że wydarzenia nie są pojedyncze, ale stanowią powrót tego samego - semestr za semestrem, zajęcia za zajęciem - złożenia są identyczne, niezależnie od pogody. Tymczasem pojedynczość zakłada nieprzekładalność doświadczenia. W każdym wydarzeniu pojawiają się inne przepływy, inne układy pozornie może podobne, ale tylko pozornie. Nie oznacza to jednak, że są one radykalnie oddzielone - doświadczenie zostaje i poprzednie wydarzenie wpływają na wydarzenie, ale na innej zasadzie niż ujawnianie praw i prawd, przepisów i rad. Niektóre złożenia rzeźbią w self bruzdy, które później modyfikują aktualne przepływy. Przykładowo, przeszłe konflikty wpływają na aktualne relacje poprzez przywoływanie upiorów. Niekiedy upiory są pozytywnymi wspomnieniami, które napełnią odwaga i nadzieją. Przeszłe wydarzenia są czymś w rodzaju warstw, które uruchamiają się, ale nie jako instrukcje obsługi, ale widmowo modyfikujące przepływy.

Praktyka, wydarzenie nie jest więc czymś, co tworzy wiedzę, ale samym współbyciem. Rolą dydaktyki ogólnej nie byłoby wiec produkowanie teorii na podstawie wyblakłych obrazów. Muzeum ruin byłoby raczej przestrzenią inspiracji. W najlepszych przypadkach stawałoby się samo przestrzenią studiowania. Gromadzenie ruin samo stawałoby się wydarzeniem. Można powiedzieć, że poza kolekcjonowaniem, dydaktyka ogólna immanencji stawałaby się praktyką praktyki, studiowaniem studiowania. Nie oznacza to przejścia na jakiś metapoziom, jak w przypadku dydaktyki transcendencji, ale rozmnażanie, wytwarzanie. Zanurzenie się w wydarzeniu powoduje zwielokrotnienie, nie zaś przeniesienie.

\section{Zakończenie}

Zarysowałem radykalną opozycję między dwiema dydaktykami, ukazując jednocześnie, że w ramach dydaktyki immanencji dydaktyka ogólna ulega transformacji, która z perspektywy akademickiej może wydawać się równoważna z jej zniesieniem. Prezentowałem dydaktykę immanencji głównie poprzez różnicowanie. W zakończeniu postaram się dokonać pozytywnej charakterystyki, z pełną świadomością niemożliwości reprezentacji procesu, o którym opowiadam. 
Dydaktyka immanencji staje się nierozróżnialna od samej sieci, jest w łączach, a nie jakimś wyodrębnionym jednym połączeniem. Istnieje tylko w sieci, w tej konkretnej. „Wiedza”, która się w niej produkuje, nie jest teorią badacza ani nie jest refleksyjnością nauczyciela, lecz raczej przynależy do tymczasowego intelektu rojowego (Lewis, 2010). To znaczy, nie tylko nie jest „własnością” indywidualnego podmiotu, ale nawet ludzkiego podmiotu - jest wytworem złożenia różnych rzeczy. Wiedza ta nie urzeczowia się w reprezentacji, nie może zostać oddzielony od spotkania/złożenia i ulega rozproszenia wraz z rozpadem sieci. Jest integralnie związana z formą współbycia.

Współbycie jest formą exodusu z maszyn akumulujących, z edukacji wyalienowanej i martwych form wiedzy. Z edukacyjnych fabryk posłuszeństwa, zastygłych form wspieranych przez maszyny dydaktyczne (Laskowski, 2011). Jest nie-badaniem, jako praktyka uruchamiania przepływów, otwierania świata i tworzenia, które jest zawsze niepowtarzalne - wydarzeniem, które tworzy horyzontalne sieci i które przez te sieci jest wspierane.

Nie wyodrębniając teorii jako czegoś zewnętrznego, nie uznając ogólnych prawd i praw, przeformułuje dydaktykę ogólną jako swoistą praktykę studiowania studiowania oraz tworzenia muzeów pełnych inspirujących kolekcji.

Tak jak między polityką transcendencji a polityką immanencji nie ma pola stycznego, ale stanowią dwa odrębne sposoby myślenia czy życia ${ }^{5}$, tak nie ma łączności między odpowiadającymi im dydaktykami. W stosunku do praktyk związanych z technicznym myśleniem, dominujących praktyk szkolenia czy biopolitycznego uczenia się i wymagań stawianych w ramach dydaktyki technokratycznej, dydaktyka immanencji wydaje się bezradna ${ }^{6}$. Dylematy tej ostatniej są nieistotne dla pierwszej, zostają odrzucone jako element „złej polityki”. Analogicznie jest w przypadku dydaktyki. Nie oznacza to, że dydaktyka immanencji nie jest w stanie wpływać na „złe praktyki”. W tym kontekście rozpoczęcie studiowania studiowania może doprowadzić do unieruchomienia maszyny i uruchomienia innej produkcji wiedzy w ramach logiki wewnętrznego zerwania. Wspomnienia oporu mogą inspirować nowe powstania.

${ }^{5}$ Doskonale radykalną różnicę ukazują najnowsze ruchy społeczne (Day, 2001), które uruchamiają politykę wydającą się zarówno dla państwowych naukowców, jak i zawodowych polityków, czymś niepolitycznym. Sam zaś ruch, jak na przykład w Argentynie czy Chiapas, wysuwa tylko jedno żądanie: „wszyscy muszą odejść”, co należy tłumaczyć jako exodus wielości z aparatu państwa i funkcjonujących w jego ramach logik, uruchamiając własne maszyny wojenne o emancypacyjnym potencjale (Sitrin, 2006; Pradzyńska, 2014).

${ }^{6}$ Nieprzystawalność tych perspektyw widać chociażby na poziomie immanentnych ruchów społecznych i oficjalnej polityki. 
Podsumowując, dydaktyka immanencji, jako dydaktyka uwikłana politycznie postpolitycznie, jest radykalnie odmienna od technokratycznej dydaktyki transcendencji uwikłanej czy to partyjnie, czy to krytycznie, czy też postpolitycznie. Jej istotowa filozoficzność nie tyle oznacza przyjęcie tej czy innej koncepcji filozoficznej i próby czytania dydaktyki czy implikowania do procesu dydaktycznego jej tez, pojęć czy co tam zostało urzeczowione. Filozoficzność nie jest tożsama z dyscypliną akademicką, ale z doświadczeniem egzystencjalnym, z określonym stylem życia i stosunkiem do innych. Stanowi ona element działających sieci, sącząc się wraz z dydaktyką, jej liniami i węzłami. Wspomniane cechy znajdują odzwierciedlenie w metodologii, którą można określić jako formę „dociekań robotniczych” (Szwabowski, 2016) czy też jako metodologii anarchistycznej opierającej się na braku metody - myśl koczownicza jest myślą bez metody (Deleuze, Guattari, 2015: 464; zob. Manning, 2016). Dydaktyka immanencji przywraca kluczowe miejsce przyjaźni i miłości, pragnieniu, które nie definiowane jest przez brak, ale posiada własną, immanentną radość (Deleuze, Guattari, 2015: 186), a tym samym bezcelowość właściwą studiowaniu. Pragnienie napędzające dydaktykę immanentną nie zostaje podporządkowane pragnieniu nadrzędnemu (nauczyciela, instytucji, systemu, prawdy, itd.), tym samym blokując drogę technikom ustanawiana współliniowości - pragnienie to raczej się rozlewa, a jedyną linię, jaką rysuje, to linia ujścia.

\section{Literatura}

Bauman Z. (2009). Nowoczesność i zagłada. Kraków.

Bednarek J. (2012). Polityka poza formą. Ontologiczne uwarunkowania poststrukturalistycznej filozofii polityki. Poznań.

Bey H. (2001). Tymczasowa Strefa Autonomiczna. Kraków.

Cleaver H. (2012). Praca w szkole i walka przeciwko pracy w szkole. „Przegląd Anarchistyczny” nr 13.

Day R.J.F. (2001). Gramsci is Dead. Anarchist Currents in the Newest Social Movements. London.

De Zeeuw D. (2014). Engaged withdrawal. Occupying politics beyond politics. "Krisis. Journal for Contemporary Philosophy" nr 1.

Deleuze D. (2016). Co mówią dzieci. [W:] G. Deleuze. Krytyka i klinika. Łódź.

Deleuze G., Guattari F. (2015). Tysiac plateau. Warszawa.

Deleuze G., Guattari F. (2017). Anty-Edyp. Warszawa.

D'Hoest, F., Lewis, T.E. (2015). Exhausting the fatigue university: in search of a biopolitics of research. "Ethics and Education" nr 10(1).

Gale K., Wyatt J. (2018). Autoethnography and Activism: Movement, Intensity, and Potential, "Qualitative Inquiry", DOI: 10.1177/1077800418800754.

Hannon A. (2014). 'Whose streets?': zones of performative occupations. “Transforming Anthropology. Journal of the Association of Black Anthropologists" nr 1(22).

Kaczmarczyk P., Madys A., Pławski M., Szczepaniak C., Szwabowski O., Wężniejewska P. (w druku). Kolektywne majsterkowanie, albo zmiana, która nie-nadchodzi. 
Kowzan P. (2017). Dydaktyka zorientowana na współpracę równych. Typy relacji ze studentami podczas wspólnej pracy badawczej. „Hybris” nr 1.

Kuhn T.S. (2001). Struktura rewolucji naukowych. Warszawa.

Laskowski P. (2011). Maszyny wojenne. Georges Sorel i strategie radykalnej filozofii politycznej. Warszawa.

Lewis T.E. (2010), Swarm intelligence: rethinking the multitude from within the transversal commons. "Cultural, Theory and Critique" nr 5(3).

Lewis T.E. (2012a). The Aesthetics of Education. Theatre, Curiosity, and Politics in the Work of Jacques Rancière and Paulo Freire. London-New York.

Lewis T.E. (2012b). Exopedagogy: On pirates, shorelines, and the educational commonwealth. "Educational Philosophy and Theory" nr 8(44).

Lewis T.E. (2013). On Study. Giorgio Agamben and educational potentiality. London-New York.

Lewis T.E. (2017). Beyond measure. Studying the educational logic of Patti Lather's Getting Lost. "Qualitative Inquiry" nr 23(4).

Lordon F. (2012). Kapitalizm, niewola i pragnienie. Marks i Spinoza. Warszawa.

Malewski M. (2010). Od nauczania do uczenia się. O paradygmatycznej zmianie $w$ andragogice. Wrocław.

Manning E. (2016). The Minor Gesture. London.

Massumi B. (2011). Semblance and Event. Activist Philosophy and the Occurrent Arts, Cambridge. London.

Negri A., Hardt M. (2012). Rzecz-pospolita. Kraków.

Pławski M., Szwabowski O., Szczepaniak C., Wężniejewska P. Friendly writing as non-inguiry: the problems of collective autothnographic writing about collective autoethnographic writing. "Qualitative Inqiury", doi: 1077800418809134.

Pospiszyl M. (2016). Zatrzymać historię. Walter Benjamin i mniejszościowy materializm. Warszawa. Pradzyńska B. (red.). (2014). Inny Meksyk. Opowieści zapatystów. Poznań.

Roos J.E., Oikonomakis L. (2013). We Are Everywhere! The Autonomous Roots of the Real Democracy Movement, tekst wygłoszony na 7. edycji ECPR General Conference: 'Comparative Perspectives on the New Politics of Dissent' Democracy of the Squares: Visions and Practices of Democracy from Egypt to the US, Sciences Po Bordeaux, 4-7 wrzesien 2013.

Sitrin M. (red.). (2006). Horizontalism: Voices of Popular Power in Argentina. Edinburgh, Oakland, West Virginia.

Szwabowski O. (2014a). Paradygmat i pedagogika. „Hybris”, nr 25.

Szwabowski O. (2014b). Demokracja, edukacja i czas (bez)rewolucji. [W:] K. Gawlicz, P. Rudnicki, M. Starnawski, T. Tokarz (red.). Demokracja i edukacja: dylematy, diagnozy, doświadczenia. Wrocław.

Szwabowski O. (2014c). Uniwersytet metropolitalny, korupcja i wychowanie przez dług. „Teraźniejszość, Człowiek, Edukacja” nr 68.

Szwabowski O. (2015). Ruch Occupy: inna demokracja, inna pedagogika. [W:] A. Olczak, P. Prüfer, D. Skrocka (red.). Edukacyjne i społeczne konteksty demokracji. Gorzów Wielkopolski.

Szwabowski O. (2016). Dociekania robotnicze. Analiza filozoficzna. „Forum Oświatowe” nr 1.

Szwabowski O. (2017). Polityczność dydaktyki. „Hybris”, nr 1.

Szwabowski O., Wężniejewska P. (2017). An (co)autoethnographic story about going against the neoliberal didactic machine?. "Journal for Critical Education Policy Studies” nr 15(3).

Zaczyński W.P. (1988). Metodologiczna tożsamość dydaktyki. Warszawa. 